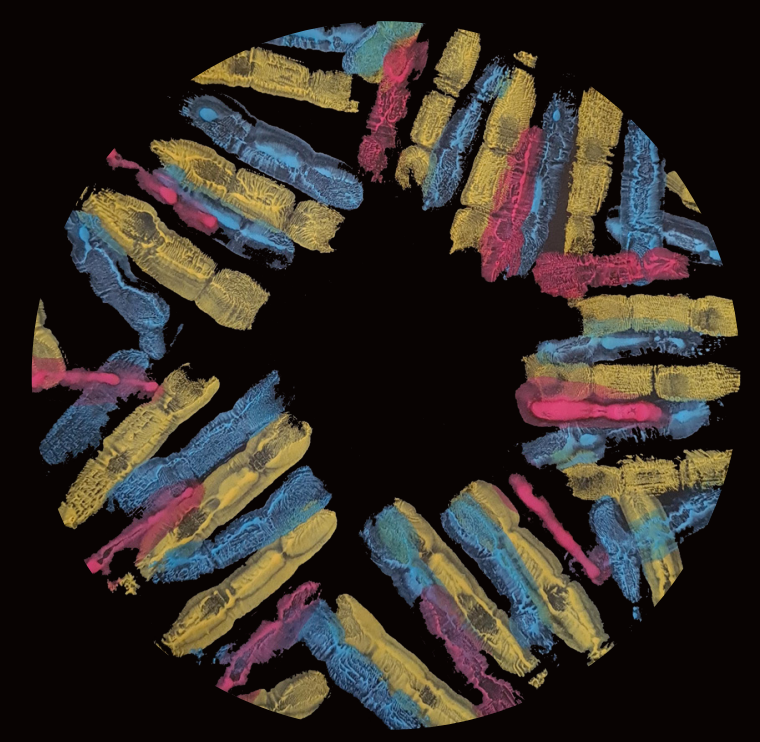

\title{
Intestinal transplantation
}

Outcome, complications and diagnostic approach

Jonas Varkey

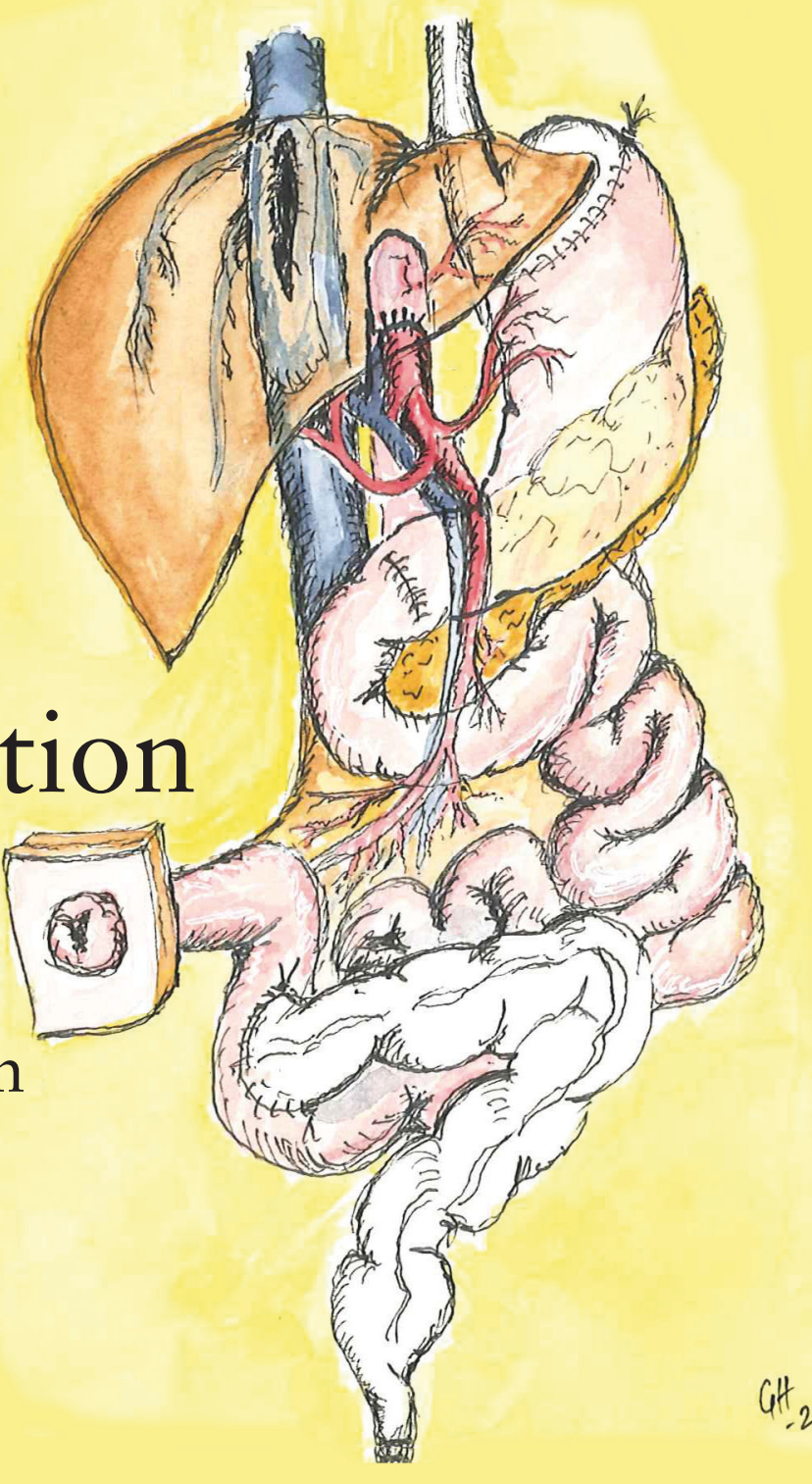

